\title{
ラネー銅触媒組織とアクリロニトリル水和反応に括ける 触媒活性に护よ湆す母合金凝固速度の影響*
}

\author{
大中逸雄** 山内 勇** 板屋光彦
}

J. Japan Inst. Metals, Vol. 56, No. 8 (1992), pp. 973-981

Effects of Solidification Rate of Mother Alloys on Structure of Raney Copper Catalysts and Their Catalytic Activity in Hydration Reaction of Acrylonitrile

Itsuo Ohnaka, Isamu Yamauchi and Mistuhiko Itaya

Department of Materials Science and Processing, Faculty of Engineering, Osaka University, Suita

To improve the catalytic activity of Raney copper catalysts for the hydration reaction of acrylonitrile which is important for producing acrylamide, their mother alloys, namely $\mathrm{Cu}-70$ at\% $\mathrm{Al}$ alloys, with and without additive elements, were solidified at various cooling rates, and the structures of the mother alloys and catalysts made by leaching $\mathrm{Al}$ from them were examined by SEM, TEM and X-ray microanalysis. The specific surface area of the catalysts was measured by the BET nitrogen-absorption technique. The activity of the catalysts was evaluated by the conversion ratio from acrylonitrile to acrylamide by the hydration reaction. As a result, a drastic increase of the catalytic activity up to about 1.8 times as high as conventional Raney copper was realized by adding 0.8 at\% of Ti or 0.7 at $\%$ of $\mathrm{V}$ and rapid solidification using the rotating-water-atomization process, while the cooling effect was smaller in the case of $\mathrm{V}$ addition. The TEM and chemical analysis revealed that the catalysts are aggregates of fine copper fibers 10 to $40 \mathrm{~nm}$ in diameter, containing 1 to 6 at\% $\mathrm{Al}$ which increased by adding the third elements. The amount of residual additive elements increased with solidification rate. The catalytic activity improvement is attributed at least to the refinement of the $\mathrm{Cu}$-fiber size. Further, the $\mathrm{X}$-ray broadening method may underestimate the $\mathrm{Cu}$-fiber size.

(Received February 4, 1992)

Keywords: rapid solidification, solidified structure, Raney-copper, copper-aluminum alloys, catalysis, specific surface area, acrylamide, acrylonitrile, hydration reaction, rotating-wateratomization

\section{I . 緒言}

急冷凝固法, 特に単ロール法により得られたアモルファ ス合金(例えば，Ni-B， Ni-P, Ni-Zr, Cu-Zr 合金など)か ら製作された触媒の水素化能が結晶質触媒に比較して著 しく良くなることが報告されている(1)-(5). 例えば，

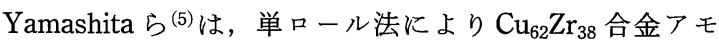
ルファスリボンを製作，粉末化し， $\mathrm{HNO}_{3}, \mathrm{HF}$ な゙で処 理した触媒で，オレフィンの水素化について検討した結 果, 触媒活性が著しく向上することを報告している.さら に船引ら(6)は，リボン状 $\mathrm{Cu}_{67} \mathrm{Ti}_{33}$ アモルファス合金を 1 規定フッ化水素酸溶液で処理して Ti を溶出し，ラネー銅 触媒を製作して，アクリロニトリルの水和反応活性につい て調べている.そして，純銅や結晶質 $\mathrm{Cu}_{67} \mathrm{Ti}_{33}$ 合金から 製作したラネー銅に比較して触媒活性が 2 倍以上向上す
ることを見出している.

また，遠心噴霧急冷法で, $\mathrm{Ni}-\mathrm{Al}$ 合金を急冷凝固させ, その後 $\mathrm{Al}$ をアルカリ水溶液で溶出, 除去することにより (以後これを“リーチング”と呼ぶ), アセトンやブチロニ トリルの水素化反応の触媒活性が, 市販触媒に比較して著 しく改善されることが報告されている(7).

一方, ラネー銅触媒 ${ }^{(8)-(10)}$ がアクリロニトリルと水を反 応させ，アクリルアミドを合成させる際の触媒として現在 利用されている。このラネ一銅触媒は, Al を約 70 at \% (50 mass\%) 含む $\mathrm{Cu}$ 合金を $0.1 \sim 10 \mathrm{~K} / \mathrm{s}$ 程度の冷却速度 で凝固させ (内寸法 $0.5 \mathrm{~m} \times 0.15 \mathrm{~m} \times 0.1 \mathrm{~m}$ 程度の金型で 鋳塊を製造)，機械的に粉砕して粉末とし，Alをリーチン グすることにより製造されている．しかしながら，ラネー 銅の母合金となる $\mathrm{Cu}-70$ at\% $\mathrm{Al}$ (以後 $\mathrm{Cu}_{30} \mathrm{Al}_{70}$ と略記) 合 金の凝固組織やラネー銅の組織に関する報告は少なく，ま た凝固時の冷却速度を変化させて製造したラネー銅のアク

\footnotetext{
* 1988年11月 4 日日本金属学会秋期大会就よび1990年 4 月 5 日同春期大会に拈いて発表

** 大阪大学工学部材料開発工学科

†大阪大学大学院生, 現在：いすず自動車(姝)
} 
リロニトリル水和反応に和ける触媒活性を調べた報告はほ とんどない．さらに，第 3 元素の添加効果もラネーニッ ケルではある程度調べられているものの ${ }^{(9)}$, ラネー銅での 報告は少ない，そこで，本研究では， $\mathrm{Cu}_{30} \mathrm{Al}_{70}$ 合金および これに第 3 元素を添加した合金の凝固組織と冷却速度, ラネー銅の微細結晶粒径，アクリルアミド合成時の触媒活 性などを調べた。な抏，第 3 元素としては，種々の元素 添加を試みたが，本報告では $\mathrm{NB}, \mathrm{VB}$ 属である $\mathrm{Ti}, \mathrm{Zr}, \mathrm{V}$, $\mathrm{Nb}$ (それぞれ 1 mass\%添加)について報告する.

\section{II. 実 験 方 法}

検討したラネー銅母合金は 29.6 at\% $\mathrm{Cu}-70.2$ at\% $\mathrm{Al}$ 合

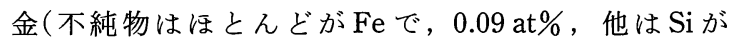
0.08 at\%であった)，执よび，これに $\mathrm{Ti}, \mathrm{Zr}, \mathrm{V}, \mathrm{Nb}$ をそれ ぞれ 0.8, 0.4, 0.7, 0.4 at\%添加したものである.これらは， 高周波溶解により製作した.

これらの母合金を, 直径 $20 \mathrm{~mm}$ の円柱状砂型鋳型, 直 径10执よび $20 \mathrm{~mm}$ の円柱状金型(高さ $150 \mathrm{~mm}$ ) に鋳込 み，鋳塊を製作し，粉砕後，20\%水酸化ナトリウム水溶 液 $400 \mathrm{~g}$ 中で, $\mathrm{Na} / \mathrm{Al}$ (モル比) $=20$, 温度 $333 \pm 5 \mathrm{~K}$ の条 件で, $600 \mathrm{~s}$ 間 $\mathrm{Al}$ をリーチングして，ラネー銅を得た。 さらに, 溶湯を直径 $1 \mathrm{~mm}$ のノズルから $288 \mathrm{~K}$ の静止水
中に噴射圧力 $0.02 \mathrm{MPa}$ で噴射したもの(以後水中噴射と 呼ぶ)，执よび回転水噴霧法 ${ }^{(11)}$ (ノズル径 $0.5 \mathrm{~mm}$ ，ガス圧 $0.15 \mathrm{MPa}$, 水温 $273 \mathrm{~K}$, 回転数 $5000 \mathrm{rpm}$ )により得られ

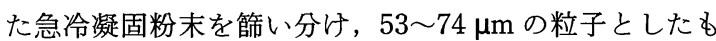
のを，上記と同一の条件でリーチングしてラネー銅を得 た.な特，これらの方法による冷却速度の程度を見積もる ため， Al-4.5 mass\% $\mathrm{Cu}$ 合金鋳塊，粉末を作り，デンドラ イト 2 次間隔を測定し，従来のデータ ${ }^{(12)}$ から，凝固区間 に物ける冷却速度を求めたところ, 砂型, $\phi 10$ 金型, $\phi 20$ 金 型鋳造，水中噴射，回転水噴霧に対し，それぞれ $0.8,5.7$, $62,230,4000 \mathrm{~K} / \mathrm{s}$ であった. これらの值から $\mathrm{Cu}_{30} \mathrm{Al}_{70}$ 合 金の潜熱を考慮しない場合の冷却速度は上記のプロセスに 対し，それぞれ $10,70,700,3000,50000 \mathrm{~K} / \mathrm{s}$ と推定され た(付録参照).

得られたラネー銅の触媒活性はアクリロニトリル $10 \mathrm{~g}$, 水 $55.0 \mathrm{~g}$ ，ラネー触媒 $7.0 \mathrm{~g}$ を混合し， $343 \mathrm{~K}$ で $2 \mathrm{~h}$ 反応 させ，生成したアクリルアミド量を求め，転化率 (=生成 したアクリルアミド量/初期アクリロニトリル量)を算出し て，転化率で触媒活性を比較した

また，このようにして得られた $\mathrm{Cu}_{30} \mathrm{Al}_{70}$ 母合金拉よび ラネー銅の組織を走査型電子顕微鏡 $(\mathrm{SEM})$, 透過型電子 顕微鏡 $(\mathrm{TEM}), \mathrm{X}$ 線マイクロアナライザー (EPMA)で観 察した。 TEM 用試料はマイクロトームによりスライス片
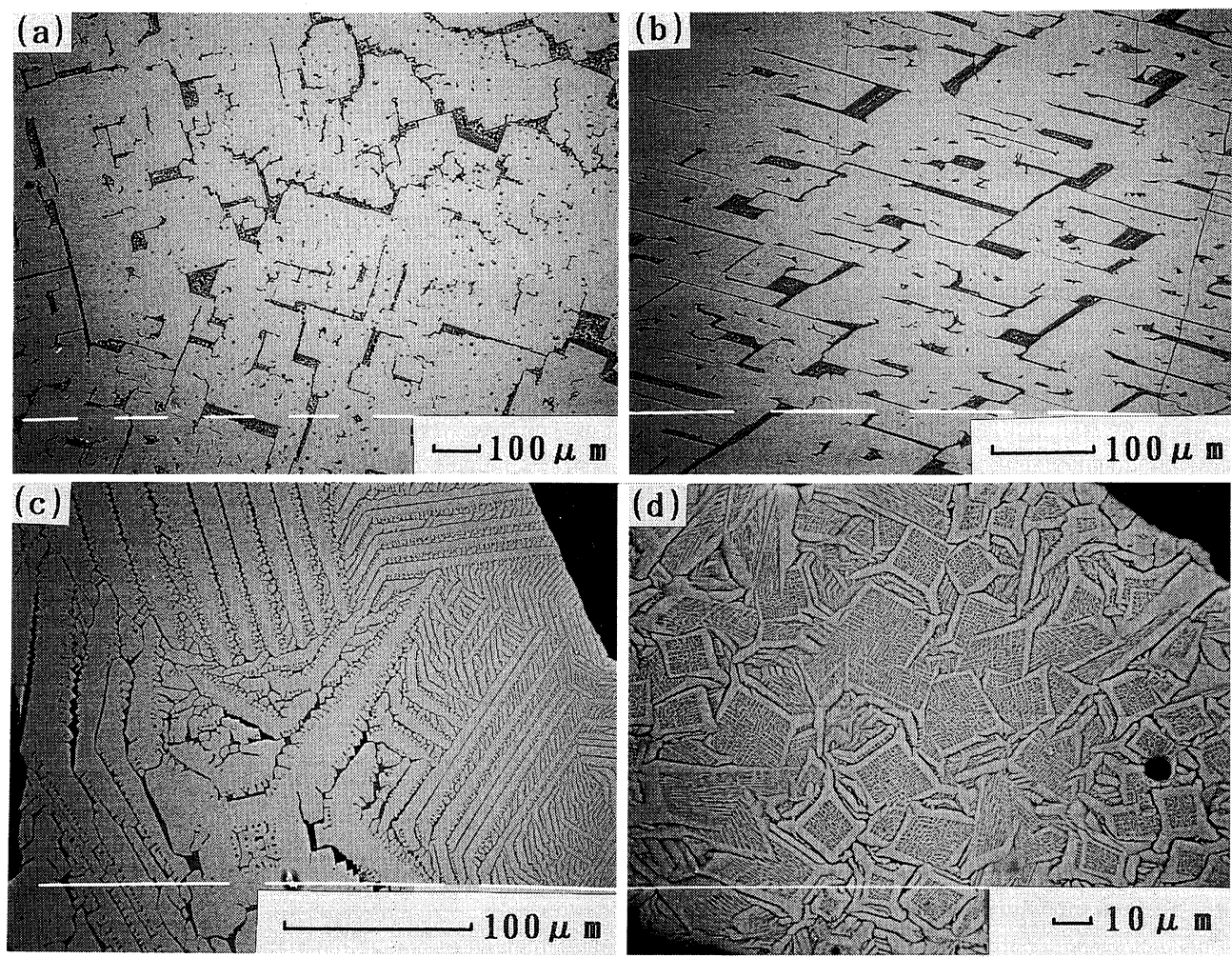

Fig. 1 SEM microstructures of $\mathrm{Cu}_{30} \mathrm{Al}_{70}$ alloy solidified at various cooling rates.

(a) Cast in sand mold, (b) Cast in metallic mold ( $\phi 10)$, (c) Ejected into water, (d) Rotating-water-atomized. 
を切出して製作した．さらに，ラネー銅の比表面積をX 線ブローディング法扣よび窒素ガス吸着法で測定した.

\section{III. 結果および考察}

\section{1. 母合金の疑固組織}

Fig. 1 亿第 3 元素を添加しない $\mathrm{Cu}_{30} \mathrm{Al}_{70}$ 合金の凝固組 織(SEM 像)を示す. 砂型拉よび金型凝固させたものは白 く見える矩形状の $\theta$ 相 $\left(\mathrm{CuAl}_{2}\right)$ と， $\alpha$ 相と $\theta$ 相からなる共 晶が黒く見えている(Fig. 1(a)，(b))。より冷却速度の早 い水中噴射 (Fig. 1(c), 前述のよ5飞冷却速度は約 3000 $\mathrm{K} / \mathrm{s}$ ) では $\theta$ 相が樹枝状に成長している.ささらに冷却速度 の早い回転水噴霧法 (Fig. 1(d), 冷却速度 $50000 \mathrm{~K} / \mathrm{s}$ ) で は矩形状の $\theta$ 相中に共晶が網目状に晶出している. このよ らに晶出相の形態は冷却速度でかなり変化したが，X線 解析では明瞭な準安定相は検出されなかった。

第 3 元素を添加してもマトリックス組織は基本的に はほぼ同じであった。代表例として、Tiを添加した $\mathrm{Cu}_{29.6} \mathrm{Al}_{69.6} \mathrm{Ti}_{0.8}$ 合金の凝固組織を Fig. 2 亿示す。砂型凝 固では針状の金属間化合物が生じた(Fig. 2(a)). EPMA 分析結果扣よび状態図からこの金属間化合物は, $\mathrm{Cu}$ 多 少固溶した $\mathrm{Al}_{3} \mathrm{Ti}$ あるいは $\mathrm{Al}_{72} \mathrm{Cu}_{3} \mathrm{Ti}_{25}{ }^{(13)}$ の可能性がある が，X 線回折では $\mathrm{Al}_{3} \mathrm{Ti}$ のみが観察された よると $\mathrm{Al}, \mathrm{Cu}, \mathrm{Ti}$ 量はそれぞれ 74.1, 1.6, 24.3 at\%であっ た).

冷却速度が早い金型凝固ではこの金属間化合物は矩形状 に変化した(Fig. 2(b))。この形態は $\mathrm{Al}_{99.1} \mathrm{Ti}_{0.9}$ 合金 $(1.6$ mass\% $\% \mathrm{Ti})$ に扮ける準安定相 $\left(\mathrm{Al}_{3} \mathrm{Ti}\right.$ 相) の形態と類似して いる.すなわち, 堀ら ${ }^{(14)(15)}$ は, $\mathrm{Al}_{3} \mathrm{Ti}$ 相は $10 \mathrm{~K} / \mathrm{s}$ 程度 の冷却速度では針状 (3 次元的には薄板状)で, 冷却速度が $3 \times 10^{3} \mathrm{~K} / \mathrm{s}$ になると花びら状になることを報告している （ただし，花びら状のものは化合物そのものではなく，Al 母相と準安定 $\mathrm{Al}_{3} \mathrm{Ti}$ 相の混合組織とされている). しかし, 本実験では花びら状ではなくファッセトがはっきりしてい る.上り冷却速度の早い回転水噴霧法で得られた粉末には SEM 招よび X 線観察では金属間化合物の晶出は認められ なかった (Fig. 2(c))．このような $\mathrm{Al}_{99.1} \mathrm{Ti}_{0.9}$ 合金との相違 は $\mathrm{Cu}$ の影響によるものであろら。すなわち $\mathrm{Ti}$ の $\mathrm{Cu}$ 中 への溶解度は徐冷の場合小さいものの, 急冷により 20 at\%程度固溶することが報告されている(16). したがって， 回転水噴霧法の場合, Ti は葟洼固溶された可能性がある し，金型の場合にも， $\mathrm{Cu}$ の影響で晶出物の形態が変化し たのであろら.

同様に，Nb，V，Zr を添加した場合，Fig. 3 亿示すよう に，砂型鋳造や金型鋳造では金属間化合物が生じた。 EPMA 分析では, これらの晶出物中の $\mathrm{Al}, \mathrm{Cu}$ 抽よび添加 元素の濃度は $\mathrm{Nb}$ 系では 73.5, 3.5, 23.0 at\%, $\mathrm{V}$ 系では $76.1,5.9,18.0$ at $\%, \mathrm{Zr}$ 系では 54.3, 40.6, 5.1 at\%であっ た。特に V 添加の場合, 準結晶と思われる 5 回対称状
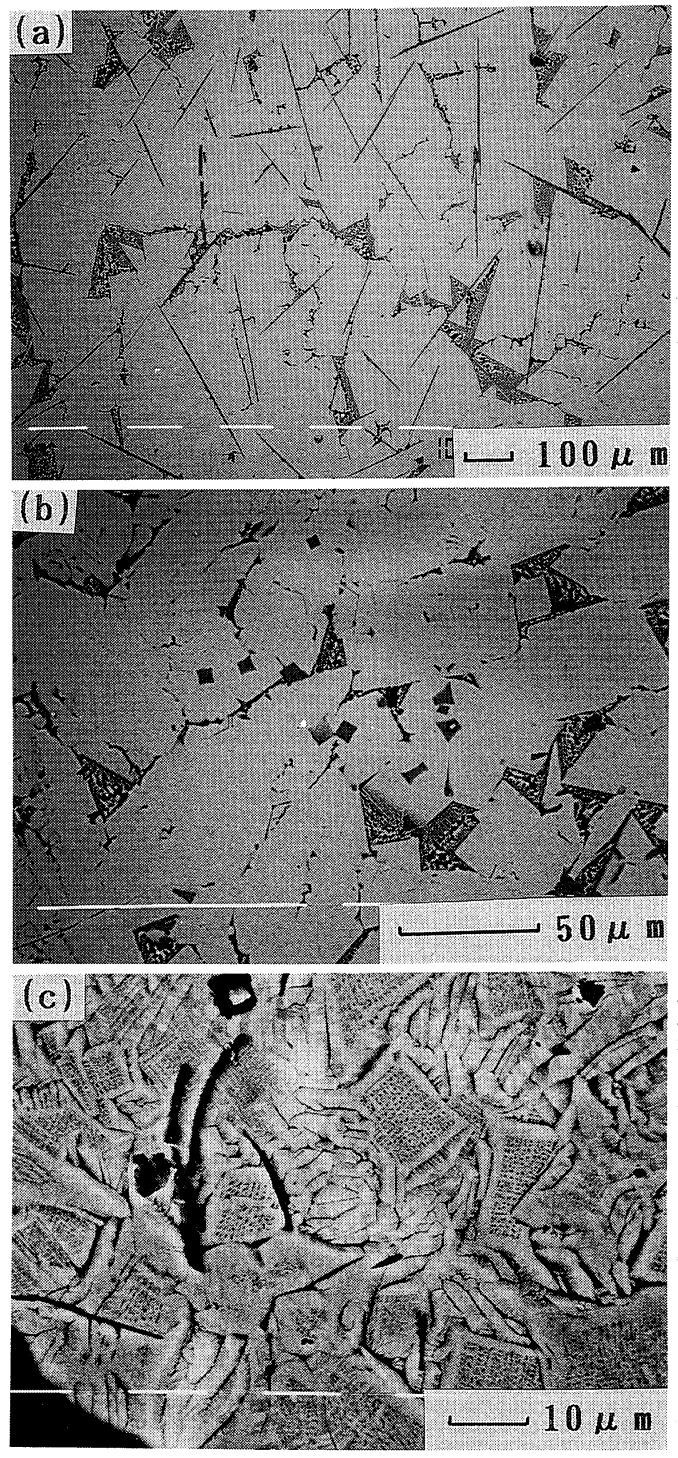

Fig. 2 SEM microstructures of $\mathrm{Cu}_{29.6} \mathrm{Al}_{69.6} \mathrm{Ti}_{0.8}$ alloy solidified at various cooling rates.

(a) Cast in sand mold, (b) Cast in metallic mold ( $\phi 10)$, (c) Rotating-water-atomized.

化合物が生じた (Fig. 3(a)，(b))。急冷凝固後焼鈍した $\mathrm{Al}_{75} \mathrm{Cu}_{15} \mathrm{~V}_{10}$ 合金や約 $14 \mathrm{at} \%$ の $\mathrm{V}$ 含む $\mathrm{Al}$ 合金を急冷凝 固させると準結晶が生じることが報告されている が(17)-(20)，本合金については今後さらに TEM などで確 認する必要がある.

回転水噴霧法の場合, これらの第 3 元素の添加による 晶出物は, Ti の場合と同様に SEM 観察やX 線分析では 見出すことができず，汇とんど固溶したものと思われる． な拈, $\mathrm{Al}$ 系 2 元合金に拈ける急冷凝固に上る固溶限の拡 大は $\mathrm{Ti}: 0.2 \sim 2$ at $\%, \mathrm{~V}: 1.4 \sim 2$ at $\%, \mathrm{Zr}: 1.2 \sim 1.5$ at $\%$ となっている(21). 

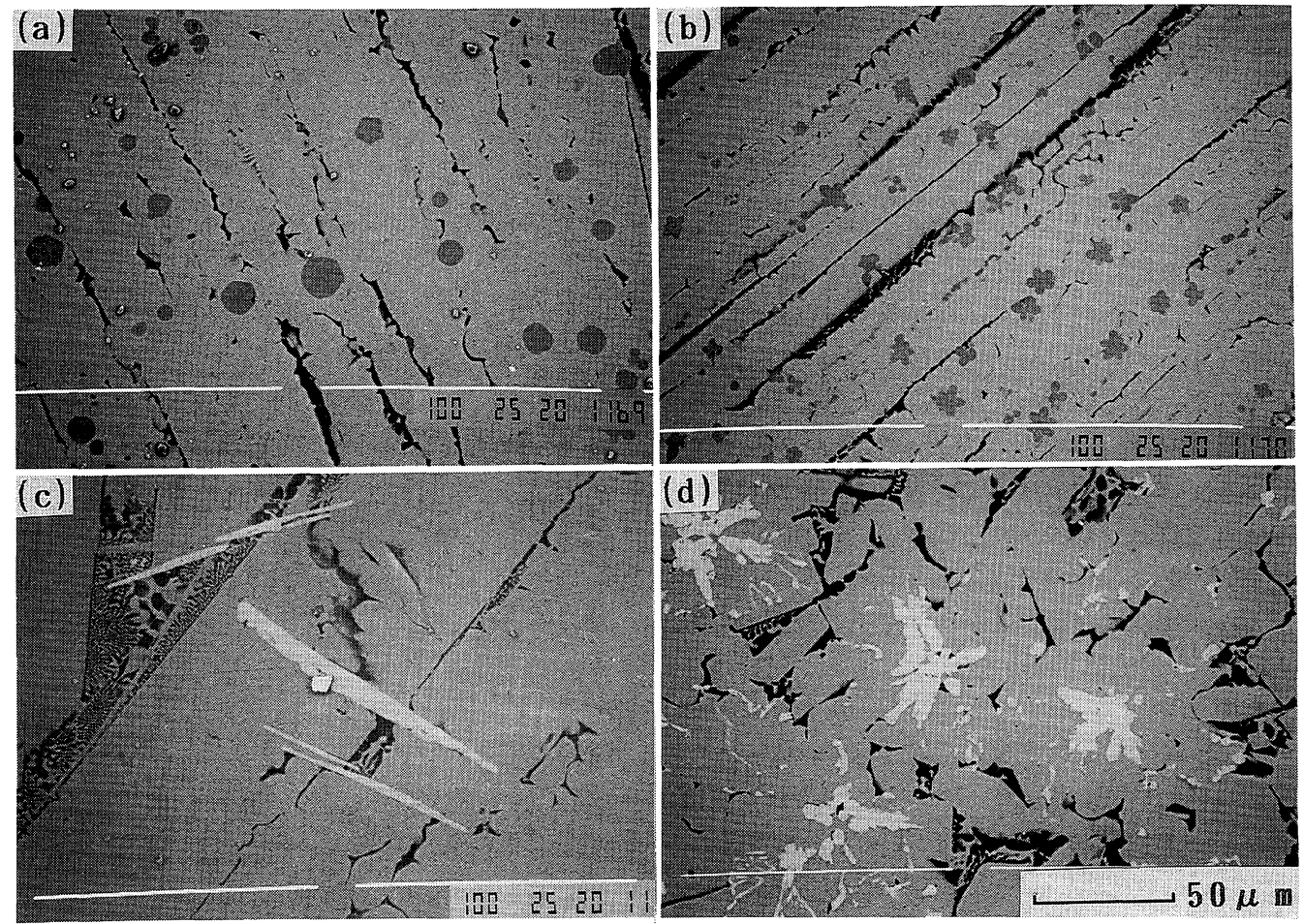

Fig. 3 SEM microstructures of $\mathrm{Cu}-\mathrm{Al}-\mathrm{X}$ ternery alloys.

(a) $X=0.7$ at $\% \mathrm{~V}$, Cast in metallic mold $(\phi 20)$, (b) $X=0.7 \% \mathrm{~V}$, Metallic mold $(\phi 10)$, (c) $X=0.4 \% \mathrm{Nb}$, Metallic mold $(\phi 20)$, (d) $X=0.4 \% \mathrm{Zr}$, Metallic mold $(\phi 20)$

\section{2. ラネ一銅の組織}

Fig. 4 飞 Ti 添加しない場合とした場合のラネー銅の SEM 組成像を示す。いずれもまず共晶部分がなくなり， ほぼ $\mathrm{Al}$ を 1 6 at\%含む(化学分析結果) $\mathrm{Cu}$ 固溶体となっ て括り，多くの亀裂が生じていた。亀裂間隔は冷却速度が 早いほど短くなった。委た Ti 添加により，一層細かい亀 裂が生じた. 亀裂発生場所と共晶との相関は特には見られ なかった．さらに晶出していた金属間化合物相もリーチン グによりなくなったが，分解途中と思われるものが見当ら なかったことから，水酸化ナトリウム水溶液で分解したの ではなく，脱落したものと考光られる.

これらのラネー銅の SEM 組成像では，共晶や化合物が なくなった他はリーチング前と極端に違う組織とはなって 扒らず，添加元素の影響ははっきりしなかった。

Table 1 にラネー銅に残留した $\mathrm{Al}$ 抢よび第 3 元素量を 示すが，第 3 元素を添加すると, 残留 $\mathrm{Al}$ が増大寸る傾向 が見られる．また，急冷により $\mathrm{Al}$ 扣よび添加元素の残留 濃度は増大して拉り，TEM 観察でラネー銅中に析出物が 観察されなかったことから，Cuへの固溶量が増大したも のと考光られる.

亀裂が生じる理由は以下の通りであろう。 $\theta$ 相(密度実 測值 $\rho\left(\mathrm{Al}_{2} \mathrm{Cu}\right)=4140 \mathrm{~kg} / \mathrm{m}^{3}, \mathrm{Cu}$ 濃度 53 mass\%) 加ら低
密度の $\mathrm{Al}$ が除去され, 高密度の純 $\mathrm{Cu}(\rho(\mathrm{Cu})=8960 \mathrm{~kg} /$ $\left.\mathrm{m}^{3}\right)$ に近い相に变化するのであるから，共晶相を無視する と,

$$
\varepsilon=\rho\left(\mathrm{Al}_{2} \mathrm{Cu}\right)\left\{1 / \rho\left(\mathrm{Al}_{2} \mathrm{Cu}\right)-0.53 / \rho(\mathrm{Cu})\right\}=0.755
$$

すなわち，約76\%の空隙あるいは收縮が発生するはずで ある.このため, 亀裂が生じるのであろら。しかしなが ら，これらの亀裂だけでは体積差と釣り合わず，ラネ一銅 中には多くの空隙が存在することが予想される.

Fig. 5 はラネー銅の TEM 像であり, 多くの空隙が分 散していることが分かる. また，ラネー銅は直径 $10 〜 40$ $\mathrm{nm}$ の繊維状あるいは微粒子の集合体であることも分かる. Young ら ${ }^{(22)(23)}$ は $\mathrm{Cu}-\mathrm{Al} 2$ 元合金から製作したラネー銅の

Table 1 Residual Al and added elements in Raney copper catalysts (at.\%). RWA : Produced through Rotating-Water-Atomization.

\begin{tabular}{l|c|c|c|c}
\hline \hline \multirow{2}{*}{ Alloy } & \multicolumn{2}{|c|}{ Cast in sand mold } & \multicolumn{2}{c}{ RWA } \\
\cline { 2 - 5 } & $\mathrm{Al}$ & Additive & $\mathrm{Al}$ & Additive \\
\hline $\mathrm{Cu}-\mathrm{Al}$ & 1.08 & - & 1.12 & - \\
$\mathrm{Cu}-\mathrm{Al}-1 \mathrm{Ti}$ & 1.84 & 1.17 & 5.16 & 1.88 \\
$\mathrm{Cu}-\mathrm{Al}-1 \mathrm{~V}$ & 2.57 & 0.59 & 5.53 & 0.92 \\
$\mathrm{Cu}-\mathrm{Al}-1 \mathrm{Zr}$ & 2.56 & 0.66 & 2.52 & 0.91 \\
$1 \mathrm{Nb}$ & 1.82 & 0.12 & 2.47 & 0.33 \\
\hline
\end{tabular}



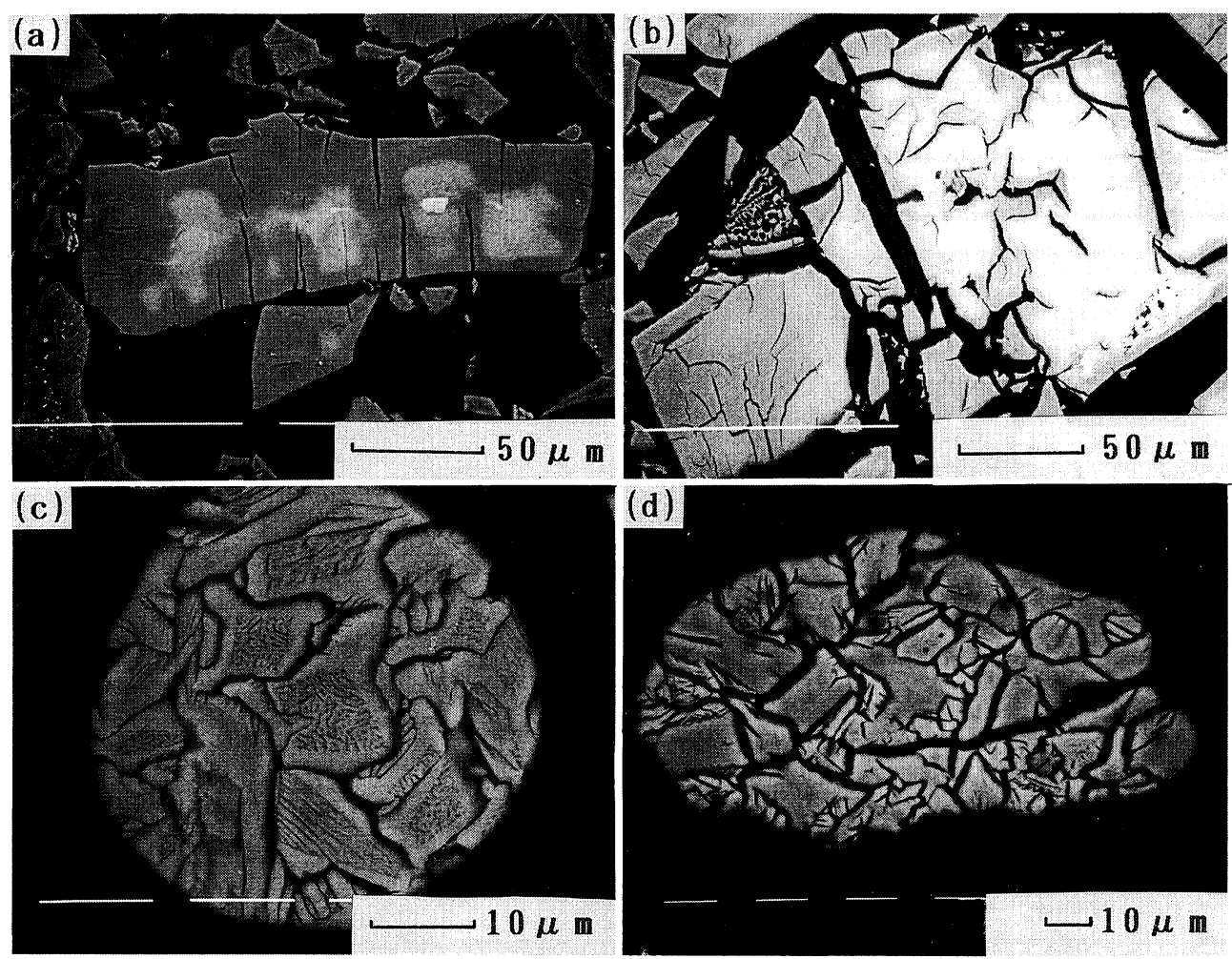

Fig. 4 SEM views of leached $\mathrm{Cu}_{30} \mathrm{Al}_{70}$ and $\mathrm{Cu}_{29.6} \mathrm{Al}_{69.6} \mathrm{Ti}_{0.8}$ alloys: (a) $\mathrm{Cu}-\mathrm{Al}$, Cast in sand mold, (b) Cu-Al-Ti, Sand mold, (c) $\mathrm{Cu}$-Al, Rotating-water-atomized, (d) $\mathrm{Cu}-\mathrm{Al}-\mathrm{Ti}$, Rotating-water-atomized.

レプリカ法および薄膜法による電子顕微鏡観察を行い，同 様の写真を得て，ラネー銅はほぼ均一な直径の棒状単結晶 の集合体で, 周囲の空隙部は連続相であることを報告して いる. 本観察結果からも同様のことが言えるが，この繊維 状銅相 (以後「Cu相」と呼ぶ) はかなり屈曲しているよう に観察される. また後述のよらに $\mathrm{Cu}$ 相の長さは短い可能 性がある.ラネー銅の立体的構造については今後の詳細な 観察が望まれる。

また，Ti 怙よび Vを添加した場合，ラネー銅の $\mathrm{Cu}$ 相 は微細化され, Ti 添加の場合, 冷却速度が大きいほど, より微細化された(Fig. 5(b1)，(b2)，Fig. 6). Nb, Zr を添 加した場合も $\mathrm{Cu}$ 相は多少微細化されたが，V 添加の場 合と同様に，冷却速度の影響はあまり見られなかった (Fig. 7).

このよらな, ラネー銅の $\mathrm{Cu}$ 相の寸法変化は $\mathrm{X}$ 線ブロ ーディング法 ${ }^{(24)}$ にるる粒径測定結果や窒素ガス吸着法に よる比表面積(BET 面積)測定でも確認された(Fig. 6). ただし，X線ブローディング法で得られた粒子寸法は TEM 像から得られたものより小さい值となった. この理 由は以下の通りであろう。まず，無添加の場合のラネー銅 の格子定数は冷却速度にあまり関係なく純銅の格子定数よ り0.1\%程度大さかった. この原因としては $\mathrm{Al}$ 执よび水素
の固溶以外に空孔が多いことが考えられる (1 at\%の Al の 固溶はVegard の法則では0.05\%程度の格子定数変化とな る)。また， $\mathrm{Cu}$ 相ごとに空孔濃度が異なり，したがって 格子定数も異なるものと考えられる. このよらに格子定数 が異なる微細 $\mathrm{Cu}$ 相の集合体であるラネー銅粉末にブロー ディング法を適用したため，粒度が過小評価されたもので あろら.なお, 水素, 空孔濃度を減少するため熱処理する と $\mathrm{Cu}$ 相が粗大化するため，これらの影響のみを評価する ことは容易ではない。

TEM 像から得られた $\mathrm{Cu}$ 相の寸法(TEM 粒子径と呼 ぶ)から比表面積を算出するため， $\mathrm{Cu}$ 相の形状を棒状と し，かつ直径 $d$ に対する長さの比(アスペクト比)を $\beta$ と すると, 比表面積 $S_{\mathrm{g}}$ は

$$
S_{\mathrm{g}}=(2+4 \beta) /(\beta \rho d)
$$

となる.ここで $\rho$ は $\mathrm{Cu}$ の密度である. Fig. 6 に示すよう に, $\beta$ を 1〜2 とすると TEM 粒子径から求めた比表面積 と BET 面積は良く一致する. 一方, X 線ブローディング 法で求めた粒子径は TEM 粒子径より小さいので, 当然の ことながら $\beta$ を 1 より小さくしないと一致せず，不合理 である. BET 面積の精度が本実験では不明であるが，比 較的正確であるとすれば(42)，この結果から，ラネー銅の $\mathrm{Cu}$ 相の長さは比較的短いものと推定される. 

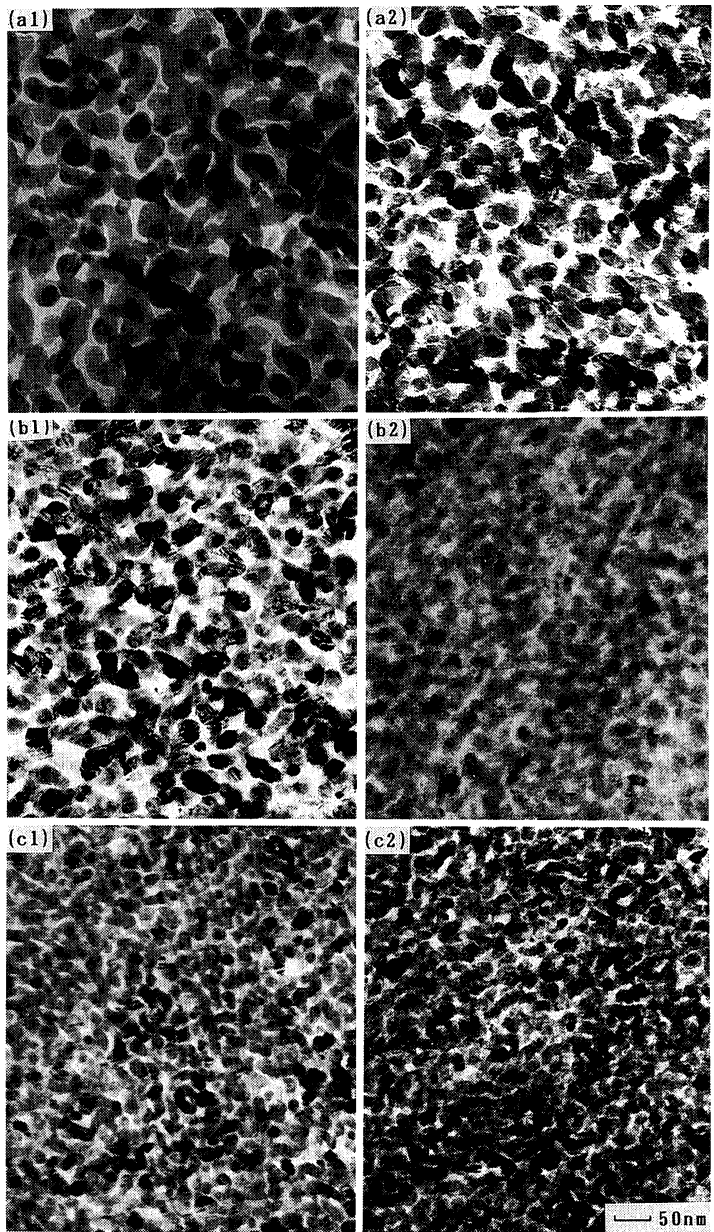

Fig. 5 TEM micrographs of Raney copper catalysts. (a1, a2): Without additive elements, (b1, b2): $0.8 \% \mathrm{Ti}$ addition, (c1, c2): $0.7 \% \mathrm{~V}$ addition. (a1, b1, $\mathrm{cl})$ and $(\mathrm{a} 2, \mathrm{~b} 2, \mathrm{c} 2)$ mean catalysts made through the metallic mold casting $(\phi 20)$ and the rotating-wateratomization, respectively.

このようなラネー銅の結晶形態の生成機構や第 3 元素 添加と冷却速度による $\mathrm{Cu}$ 相の寸法変化の機構は良く分か らない. Young ら (23)(25)-(27)は,リーチングは $\mathrm{Cu}$ 相と溶 液相が並列して進行し，Cu 相が層状に成長するモデルを 提案している $($ Fig. 8). そして，パーライト変態や共析変 態に扣ける変態進行速度と層間隔の理論式(28)-(34)を応用 して, 反応速度と空隙間隔 (ポア間隔)の関係を調べ, リー チングは $\mathrm{Al}$ 原子の $\mathrm{Cu} / \theta\left(\mathrm{Al}_{2} \mathrm{Cu}\right)$ 相界面拡散により律速さ れるとしている(26)(27).

しかしながら，このモデルではリーチング速度と空隙間 隔の関係が与えられるだけである．このため共析変態の場 合には，最大成長速度，最大エントロピー生成速度，限界 安定性などが検討されているが(34)，リーチングの場合に ついての検討はなされていない.

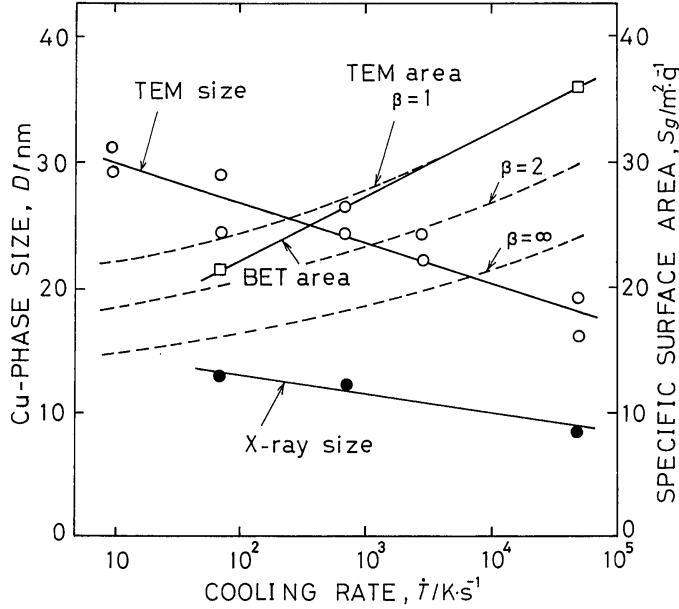

Fig. 6 Change in Cu-phase size in Ti-added catalyst and specific surface area with cooling rate during solidification. TEM area means specific area calculated by using $\mathrm{Cu}$-phase size measured by TEM and Eq. (1).

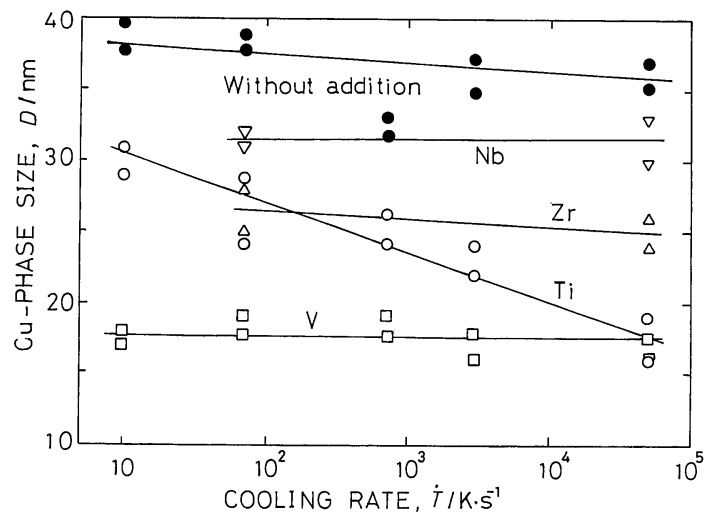

Fig. 7 Cu-phase size change in Raney copper catalysts with cooling rate and added elements.

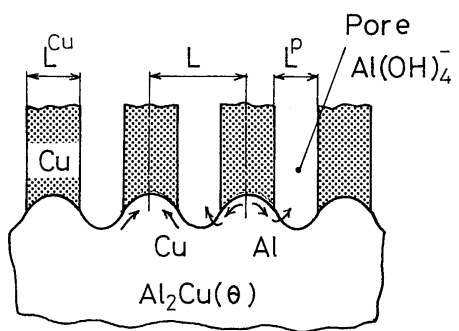

Fig. 8 Leaching model by Young et al (25)(26).

さらに, このモデルでは $\theta$ 相が $\mathrm{Cu}$ 相と溶液相に変態す ると考えられているが，このようなモデル化では，リーチ ングの機構と物理的イメージが分かりにくい，例えば， $\mathrm{Al}$ の拡散の駆動力もはっきりしないし，界面拡散係数の 


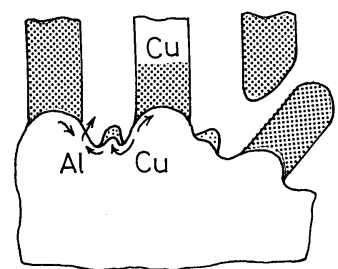

Fig. 9 Nucleation of $\mathrm{Cu}$-phase between $\mathrm{Cu}$ rods.

値や界面幅の値の妥当性の評価も容易ではない，今後, 電 気化学的な観点(例えば $\theta$ 相のミクロなガルバニック腐食) からの解析や水素原子による $\theta / \mathrm{Cu}$ 相界面の原子的構造変 化などを考慮したより詳細な検討が必要であるう．さら に, 層状, 棒状から球状への形状変化 ${ }^{(35)(36)}$ も考虑する必 要があうう。

また， $\mathrm{Al}$ が水酸化ナトリウムとして選択的にリーチン グされ，不安定となった $\mathrm{Cu}$ 原子が結晶格子を組むことに なるが，このためには $\mathrm{Cu}$ 相の核が必要であり，Fig. 9 に 示すように $\theta$ 相の分解中に $\mathrm{Cu}$ 相の核が多い注ど $\mathrm{Cu}$ 相は 微細化されるのではなかららか.

$\mathrm{Cu}$ 相の核としては $\mathrm{Cu}$ 原子のみからなる均質核と $\mathrm{Cu}$ 原子と他原子が結合した異質核が考兄られる。Tiはこの 観点からは異質核形成に有利であったとも考光られる．異 質核形成元素としては $\mathrm{Al}$ よりも $\mathrm{Cu}$ と結合力が強く, $\mathrm{Cu}$ の格子を形成するのに都合の良い元素といらことになろら が, 今のところ $\theta$ 相中での第 3 元素と $\mathrm{Cu}$ との結合力の強 さや原子配置は明確ではなく今後の検討が必要である.

な拈，イオン結合性を評価できる電気陰性度差は， $\mathrm{Cu}$ と $\mathrm{Nb}, \mathrm{Ti}, \mathrm{V}$ 間では0.3であり， Cu と $\mathrm{Zr}$ の差は 0.5 とむし ろ大きい $(\mathrm{Al}$ と $\mathrm{Nb}, \mathrm{Ti}, \mathrm{V}, \mathrm{Zr}$ の差は一0.1あるいは0.1と 小さい). しかし $\mathrm{Zr}$ の微細化効果は $\mathrm{Ti}, \mathrm{V}$ より小さく, こ の電気陰性度と $\mathrm{Cu}$ 相の微細化の程度とは直接的な関係は ない。また，ラネー銅に拈ける残留濃度(Table 1)からも 結合力が判定できると思われるが，Ti はともかく，残留 濃度が低いV 添加の方が $\mathrm{Zr}$ より微細化している。したが って，残留濃度だけからも微細化の判定はできない。

さらに, リーチング時にはかなりの活性水素が発生す る. したがって, 水素と結合力の強い $\mathrm{Ti}$ 添加などでは, この活性水素の影響も考慮する必要があるかも知れない， いずれにしても, 微細化の機構については今後の課題とし たい.

\section{3. 触媒活性}

Fig. 10 亿種々の冷却速度で製作した $\mathrm{Cu}_{29.6} \mathrm{Al}_{69.6} \mathrm{Ti}_{0.8}$ 拉 よび $\mathrm{Cu}_{29.6} \mathrm{Al}_{69.7} \mathrm{~V}_{0.7}$ 粉末から得られたラネー銅のアクリル アミド転化率とその冷却速度の関係を示した。また，

Fig. 11 には砂型鋳造から得られたラネー銅と回転水噴霧 法で得られたラネー銅の転化率を比較した。

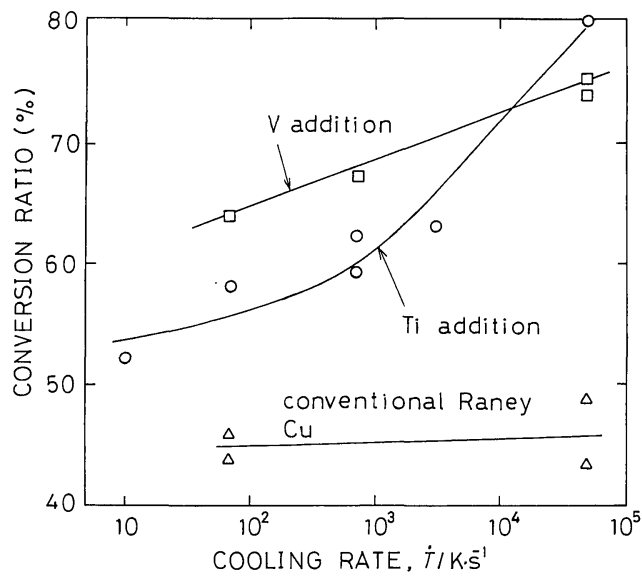

Fig. 10 Change in conversion ratio from acrylonitrile to acrylamide with cooling rate during solidification.

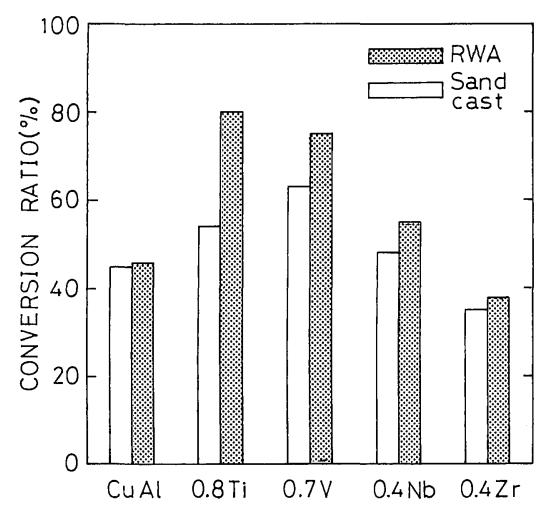

Fig. 11 Comparison of conversion ratio obtained by using Raney copper catalysts made from slow (sand mold casting) and rapid (Rotating-Water-Atomization) solidification processing.

現在, 実用化されている触媒は, 無添加で泠却速度が最 も低いものに相当して拉り，Ti拈よびVの添加により， 触媒活性が著しく向上することが分かる(従来のラネ一銅 に対し, Ti 添加で約 $180 \%, \mathrm{~V}$ 添加で約 $170 \%$ の向上)．ᄂ かし，同じ $\mathrm{NB}, \mathrm{VB}$ 属である $\mathrm{Nb}, \mathrm{Zr}$ を添加しても効果 は少なく，冷却速度依存性があまり見られない。

触媒能が向上する理由としては，(a)比表面積の増大，(b) 化学活性点の増大, (c)活性点に打ける活性自体の向上, な どが考えられる.

Ti 添加の場合, Fig. 6,10 から分かるよらに，比表面積 の増大とともに，触媒効果が増大していることが分かる． したがって, この場合の触媒能の向上は比表面積の増大が 主な原因であろう。しかし，Vを添加した場合も $\mathrm{Cu}$ 相が 微細化され比表面積は増大しているものの, 冷却速度が大 きくなると触媒活性が上昇するのに $\mathrm{Cu}$ 相の寸法は汪とん， 
ど同じである.したがって，この場合，比表面積のみなら ず，化学的効果 ((b), (c)) も考えねばならない. 化学的効果 については今後の検討が必要である.ささらに，添加元素の 残留量の影響も考慮する必要があろらが, 添加量を 2 倍 程度にしても触媒活性はあまり変化しなかった.

な挔，船引ら ${ }^{(6)}$ は， $\mathrm{Cu}_{67} \mathrm{Ti}_{33}$ 合金の場合，アモルファス 合金をリーチング(方法は本実験の場合と異なる)した触媒 の方が，結晶質合金をリーチングしたものより，触媒活性 (転化率)が約 $6 \%$ から $12 \%$ と約 2 倍大さくなることを報告 している. 本実験での合金系(単ロール法など通常の方法 でのアモルファス化は容易でない)でもアモルファス化に より，活性が更に向上するかも知れないが，著しい改善は 期待できないであろう．これは本実験での触媒活性は上記 のものより 6 倍以上大きく, 高活性のもの㴗どさらに改 善するのは容易ではないからである.むしろ, 重要なこと は，本実験結果は触媒活性の向上にはアモルフ ァス化が必 ずしも必要条件ではないことを示していることで，これは 工業的には望ましいことである。

さらに, 急冷凝固による触媒活性向上の理由として, 残 留 $\mathrm{Al}$ の増大が考えられるが，第 3 元素として, Ni を添加 した場合，残留 $\mathrm{Al}$ の増大とともにむしろ活性は低下する という実験データを得ている，したがって，可能性は少な いが， Ti, V 添加の場合にもこれを確認する必要があるか も知れない.

なお，回転水噴霧法でラネ一銅母合金粉末を製造すれ ば，このように触媒能も改善できる可能性があり，粉砕工 程を省略できるため従来法より有利であろう。

\section{N. 結 論}

(1) $\mathrm{Al}-70$ at\% $\mathrm{Cu}$ 合金に Ti あるいは V を 1 mass\%添 加し, 回転水噴霧法により急冷凝固させた後, $\mathrm{Al}$ を溶出 してラネー銅を製作することにより，アクリロニトリルか らアクリルアミドへの転化率を, 従来のラネー触媒より著 しく大さい $70 \sim 80 \%$ 程度 (これは従来触媒の $1.7 \sim 1.8$ 倍に 相当)とすることができることを見出した．また，この方 法では粉砕工程を省略できるので, 従来法より有利であ る.

（2） V 添加の場合，急冷凝固の触媒活性への影響は $\mathrm{Ti}$ 添加の場合ほど大きくはなかったまた， $\mathrm{Ti}, \mathrm{V}$ と同じ $\mathrm{NB}$ ，VB属である $\mathrm{Zr}, \mathrm{Nb}$ の添加効果はあまりなかった.

（3）本ラネー銅は直径 10 40 nm の比較的短い繊維状 の微細 $\mathrm{Cu}$ 相の集合体であり，上記触媒活性の向上は少な くとも $\mathrm{Cu}$ 相の微細化による比表面積の増加が寄与してい る.ただし， V, Nb, Zr 添加の場合， $\mathrm{Cu}$ 相の微細化への 冷却速度の影響はほとんどなかった。

（4） $\mathrm{Al}-\mathrm{Cu}$ 母合金に Ti， Zr， V， Nb を添加すると凝固時 の冷却速度が $700 \mathrm{~K} / \mathrm{s}$ 程度以下では金属間化合物が生じ たが， $50000 \mathrm{~K} / \mathrm{s}$ 程度では生じなくなった。
（5）ラネー銅は $\mathrm{Al}$ を 1 から 6 at\%程度含み，第 3 元素 を添加すると $\mathrm{Al}$ の残留濃度が増加した。 また，急冷凝固 により $\mathrm{Al}$ 㧊よび第 3 元素の残留濃度は増大した。

(6) X 線ブローディング法では微細銅相の寸法を過小 評価する危険性がある．また TEM 観察による $\mathrm{Cu}$ 相の直 径から算出した比表面積と, 窒素ガス吸着法による比表面 積の測定結果は $\mathrm{Cu}$ 相のアスペクト比を 1〜2 とすること により一致した.

本研究に和ける TEM 観察や $\mathrm{Cu}-\mathrm{Al}$ 合金の物性值調查 等で怙世話になった大阪大学 森 博太郎助教授, 田中敏宏 博士に謝意を表します。

\section{文献}

(1) F. Nozaki and R. Adachi: J. Catal., 40(1975), 166.

(2) A. Yokoyama, H. Komiyama, H. Inoue, T. Masumoto and H. M. Kimura: J. Catal., 68(1981), 355.

( 3 ) S. Yoshida, H. Yamashita, T. Funabiki and T. Yonezawa: J. Chem. Soc., Faraday Trans. 1, 80(1984), 1435

(4) H. Yamashita, T. Funabiki and S. Yoshida: J. Chemi. Soc., Chem. Comuun., (1984), 868.

( 5 ) H. Yamashita, M. Yoshikawa, T. Kaminade, T. Funabiki and S. Yoshida: J. Chem. Soc., Faraday Trans. 1, 82(1986), 707.

（6）船引卓三，尾松俊宏，八瀬 誠，山下弘巳，吉田 郷弘：日本化学会春季年会, 講演番号 1B40，(1986. 4. 1), 31 .

( 7 ) C. S. Brooks. F. D. Lemkey and G. S. Golden: Rapidly Solidified Amorphous and Crystalline Alloys, Ed. by B. H. Kear, B. C. Giessen and M. Cohen, Elsevier Science Pub. Co., (1982), p. 397.

(8) F. Matsuda: Chemtech., 7(1977), 306.

（9）久保松照夫, 小松信一郎：ラネ一触媒, 共立出版, (1971)

（10）浅野志郎 : 現代化学,（1984）5, 40 .

(11) 大中逸雄, 福迫達一, 堤 浩章 : 日本金属学会誌, 46(1982), 1095.

(12) R. Mehrabian: Rapidly Solidification Processing, Principles and Technologies, Ed. by R. Mehrabian, B. H. Kear and M. Cohen, Claitor's Publ., (1978), 9.

(13) A. Raman and K. Schubert: Z. Metallkde., 56(1965), 99.

（14）堀 茂徳, 田井秀男, 成田幸郎 : 軽金属, 32(1982), 596.

(15) S. Hori, H. Tai and Y. Narita: Rapidly Quenched Metals, Ed. by S. Steeb and H. Warlimont, Elsevier Science Pub., (1985), 911.

(16) B. C. Giessen and D. Szymanski: J. Appl. Crystallogr., 4(1971), 257.

(17) A. Inoue, L. Arnberg, B. Lehtinen, M. Oguchi and T. Masumoto: Metall. Trans., 17A(1986), 1657.

(18) E. Matsubara, Y. Waseda, A. P. Tsai, A. Inoue and T. Masumoto: Z. Natur., 43a(1988), 505.

(19) K. V. Rao, J. Filder and H. S. Chen: Europhys. Lett., 1(1986) 12, 647

(20) Y-W. Kim and F. H. Froes: Materials Science and Engineering, 98(1988), 207.

(21) H. Jones: Aluminium, 54(1987), 274.

(22) J. Szot, D. J. Young, A. Bourdillon and K. E. Easterling: Phil. Mag. Lett., 55(1987), 109. 
(23) D. J. Young: Advances in Phase Transitions, Ed. by J. D. Embury and G. R. Purdy, Pergamon Press, Oxford, (1988), 116.

(24) C. E. Pearce and D. Lewis: J. Catalysis, 26(1972), 318.

(25) J. B. Friedrich, D. J. Young and M. S. Wainwright: J. Electrochem. Soc., 128(1981), 1845.

(26) A. D. Tomsett, D. J. Young and M. S. Wainwright: J. Electrochem. Soc., 131(1984), 2476.

(27) N. I. Onuoha, A. D. Tomsett, M. S. Wainwright and D. J. Young: J. Catal., 91(1985), 25.

(28) C. Zener: Trans. AIME, 167(1946), 550.

(29) D. Turnbull: Acta Metall., 3(1955), 55.

(30) J. W. Cahn: Acta Metall., 4(1956), 449.

(31) M. Hillert: Jernkont. Ann., 141(1957), 757.

(32) J. W. Cahn: Acta Metall., 7 (1959), 18.

(33) B. E. Sundquist: Acta Metall., 16(1968), 1413.

(34) M. P. Puls and J. S. Kirkaldy: Metall. Trans., 3 (1972), 2777.

(35) H. P. Stuwe and O. Kolednik: Acta Metall., 36 (1988), 1705

(36) E. Werner: Acta Metall., 37(1989), 2047.

(37) K. C. Mills: J. Chem. Thermodynamics, 9(1977), 43.

(38) O. Kubaschewski and C. B. Alcock: Metallurgical Thermochemistry. 5th, Ed., Pergamon Press, New York, (1979).

(39) Smithells Metals Reference Book, Sixth Ed., Ed. by E. A. Brandes, Butterworths, London, (1983).

(40) K. Kornemann and F. Sauerwald: Z. Metallkde., 14(1922), 10.
（41）山内 勇, 川元 暁, 大中逸雄, 福迫達一：日本金 属学会誌, 47(1983), 1016.

(42) A. D. Tomsett, M. S. Wainwright and D. J. Young: Applied Catalysis, 12(1984), 43.

\section{[付録]}

$\mathrm{Cu}_{30} \mathrm{Al}_{70}$ 合金の凝固区間 $(\Delta T)$ に特ける冷却速度を求め るには $\theta$ 相や共晶の潜熱データなどが必要である.ここで はこれらのデータに基づく誤差を避けるため, 潜熱を放出 しない場合の冷却速度 $T\left(\mathrm{Cu}_{30} \mathrm{Al}_{70}\right)$ を推定した. 仮定とし ては, $\mathrm{Al}-4.5$ mass\% $\mathrm{Cu}$ 合金の場合と熱流速が等しく，物 性値の温度依存性がないとしたことである.この場合, 次 式が成立する：

$$
\rho C p V T\left(\mathrm{Cu}_{30} \mathrm{Al}_{70}\right)=\rho(C p+\Delta H / \Delta T) V T(\mathrm{Al}-4.5 \mathrm{Cu})
$$

ここで, $V$ は鋳塊微小部分あるいは液滴 1 個の体積であ り, 密度 $\rho$, 比熱 $C p$ は $\mathrm{Cu}_{30} \mathrm{Al}_{70}, \mathrm{Al}-4.5 \mathrm{Cu}$ 合金に対しそ れぞれ 4040,2510 kg/m $30.27,1.0 \mathrm{~kJ} /(\mathrm{kgK}), \mathrm{Al}-4.5 \mathrm{Cu}$ 合金の潜熱 $\Delta H$ は $394 \mathrm{~kJ} / \mathrm{kg}, \Delta T$ は $90 \mathrm{~K}$ とした(37)-(40).

回転水噴霧法では通常 $10^{5} \mathrm{~K} / \mathrm{s}$ 程度の冷却速度が得ら れ(11), 本実験の場合多少小さめの值となっているが，冷 却されにくい(41) $\mathrm{Al}$ 合金のデータを使用したことに原因が あるのかもしれない. したがって, 本推定值は概略值であ る. 